OPEN ACCESS

Edited by:

Sanjay K. Gupta,

Indian Institute of Agricultural

Biotechnology (ICAR), India

Reviewed by:

Zhang Min,

China Institute of Water Resources and Hydropower Research, China

Tom William Bell,

Woods Hole Oceanographic Institution, United States

*Correspondence:

Chaotian Xie

ctxie@jmu.edu.cn

Kai Xu

kaixu@jmu.edu.cn

Specialty section:

This article was submitted to

Aquatic Physiology,

a section of the journa

Frontiers in Marine Science

Received: 18 April 2021

Accepted: 14 June 2021

Published: 05 July 2021

Citation:

Xu N, Wang W, Xu Y, Ji D, Chen C, Xie C and Xu K (2021) Effects of Nutrient Availability on the Release of Dissolved and Particulate Organic Carbon by Pyropia haitanensis and lts

Implications.

Front. Mar. Sci. 8:696938 doi: 10.3389/fmars.2021.696938

\section{Effects of Nutrient Availability on the Release of Dissolved and Particulate Organic Carbon by Pyropia haitanensis and Its Implications}

\author{
Ningning $X u^{1,2,3}$, Wenlei Wang ${ }^{1,2,3}$, Yan $X u^{1,2,3}$, Dehua Ji ${ }^{1,2,3}$, Changsheng Chen ${ }^{1,2,3}$, \\ Chaotian Xie ${ }^{1,2,3 *}$ and Kai $\mathrm{Xu}^{1,2,3 *}$ \\ ${ }^{1}$ Fisheries College, Jimei University, Xiamen, China, ${ }^{2}$ Key Laboratory of Healthy Mariculture for the East China Sea, Ministry \\ of Agriculture, Xiamen, China, ${ }^{3}$ Fujian Engineering Research Center of Aquatic Breeding and Healthy Aquaculture, Xiamen, \\ China
}

As an important component of the coastal-offshore ecosystem, Pyropia haitanensis aquaculture is continually being challenged due to rapid environmental changes because of global climate change and anthropogenic pressures. To explore the effect of nutrient availability on carbon metabolism by $P$. haitanensis, two strains of thalli were incubated for 15 days under four different concentrations of nitrogen and phosphorus. Significant increases in carbon, nitrogen, and phosphorus contents were observed in the algal tissue after the nitrates and phosphates enrichment, leading to elemental stoichiometry gradually approaching the Redfield ratio. Our results also showed a positive correlation between carbon or phosphorous accumulation and growth rate. Furthermore, under the natural seawater conditions, the release rates of dissolved organic carbon (DOC) and particulate organic carbon (POC) were highest, and more DOC was released than POC. The release rates tended to decrease with nutrient enrichment. The average proportions of DOC compared to total carbon were $6.3 \%-25.7 \%$, while the average proportions of POC compared to total carbon were $2.1 \%-5.4 \%$. Our results support the proposed importance of $P$. haitanensis in contributing the DOC and POC that play a significant role in the biological carbon pump and in sustaining marine aquaculture ecosystems in eutrophic environments.

Keywords: Pyropia haitanensis, eutrophication, particulate organic carbon, dissolved organic carbon, elemental ratio, tissue carbon, nitrogen, phosphorus contents

\section{INTRODUCTION}

The global environment is changing at an unprecedented rate and is likely to severely modify current marine ecosystems; possible effects include eutrophication, increase in global temperatures, rise in $\mathrm{pCO}_{2}$, and regional changes in precipitation. These changes will have various consequences on the functions and structures of ecosystems. As a direct consequence of the growing human population and increased settlement, nutrient inputs to coastal waters have increased worldwide; this is the so-called eutrophication, a growing threat to global coastal ecosystems. Strokal et al. (2014) predicted that from 2000 to 2050, the total nitrogen and phosphorus inputs in the coastal 
seas of China will increase by $30 \%-200 \%$. This was supported by a recent study by Tong et al. (2015), who found that the nutrient transport from the eight major rivers of China into the marine coastal waters strongly increased from 2006 to 2012. The degradation of water resources by eutrophication can result in loss of the services or amenities that these aquatic resources provide. Negative effects include harmful algal blooms, hypoxia, and changes in species composition (Rabalais et al., 2009; Teichberg et al., 2010). Hence, eutrophication is one of the most prominent environmental problems of coastal ecosystems in China.

Marine macroalgae (seaweeds) play a significant role in ecological restoration of the marine environment (Wahl et al., 2015; Xiao et al., 2021). For example, nutrient removal by macroalgae aquaculture can improve water quality and inhibit harmful algal blooms in severely eutrophic areas (Yang et al., 2015). China accounts for about $47.9 \%$ of the global seaweed aquaculture production, and Pyropia haitanensis is one of the most economically important seaweeds in East Asia (FAO, 2018). Thus, large-scale cultivation of macroalgae in coastal areas of China can not only produce economic benefits but also provide ecological value to society.

As the dominant primary producers in coastal areas, the global net primary production of macroalgae is larger than that of other vegetated coastal habitats, contributing approximately 1020-1960 Tg of carbon $\mathrm{yr}^{-1}$ (Krause-Jensen and Duarte, 2016). Thus, the large-scale cultivation of macroalgae could largely contribute to the local carbon cycle by release of organic matter to adjacent ecosystems, where the organic matter can be stored, consumed, or buried (Lobban et al., 1994; Verdugo et al., 2004). For example, the dissolved organic carbon (DOC) and particulate organic carbon (POC) released by macroalgae are major sources of carbon sequestration through the driving mechanisms of biological and microbial carbon pumps (Jiao et al., 2010; Ortega et al., 2019). Calculations suggest that about $25 \%$ of the carbon exported by macroalgae is sequestered in long-term reservoirs such as the deep sea and coastal sediments (Duarte and Cebrián, 1996; Krause-Jensen and Duarte, 2016). Macroalgae therefore have numerous geochemical and ecological functions and the potential to regulate carbon dynamics in coastal ecosystems (Mann, 1973; Lobban et al., 1994).

Macroalgae play an important role in coupling multiple nutrient cycles; as such, they have been important in the development of the field of ecological stoichiometry (Duarte, 1992; Xiao et al., 2017). The ecological stoichiometry of essential biological elements such as $\mathrm{C}, \mathrm{N}$, and $\mathrm{P}$ is significant for understanding the function of marine ecosystems. Redfield et al. (1934) found the average atomic C:N:P ratio of phytoplankton to be $106: 16: 1$, a ratio that has subsequently been enshrined as the Redfield ratio (Redfield et al., 1934; Gruber and Deutsch, 2014). The ratio has been widely applied to the analyses of the nutrient status of macroalgae (Duarte, 1992), but the overall effects of $\mathrm{N}$ and $\mathrm{P}$ concentrations on the elemental stoichiometry ratio of macroalgae have been poorly characterized. The increased concentrations of $\mathrm{N}$ and $\mathrm{P}$ during seawater eutrophication can potentially influence the physiological functions of algae. For example, nutrient availability could change the carbon metabolism of microalgae, including photosynthetic carbon fixation, $\mathrm{CO}_{2}$ concentration mechanism, and the release of organic carbon (Giordano et al., 2005; Falkowski and Raven, 2013; Thornton, 2014). Additionally, nutrient enrichment can influence the biochemical composition of macroalgae, e.g., stimulating the synthesis of protein and fatty acids in Ulva rigida, and pigments and amino acids in Pyropia yezoensis (Gao et al., 2017; Gao et al., 2018; Gao et al., 2019). However, to date, the effect of nutrient availability on the elemental composition and information on the release of organic carbon of $P$. haitanensis remain unknown. Thus, a better understanding of exudate release by $P$. haitanensis, including how nutrient limitation or enrichment influences the quantity and form of $\mathrm{C}$ exudates, would increase our understanding of element cycles in coastal ecosystems.

To study the effect of nutrient availability on element accumulation and the release of POC and DOC by P. haitanensis, we cultured $P$. haitanensis under four different concentrations of $\mathrm{N}$ and $\mathrm{P}$, and then investigated the release rates of DOC, POC, and tissue elemental ratios. The goal of our study was to provide helpful insight into how nutrient availability affects the release and accumulation of organic carbon by $P$. haitanensis. Such knowledge will support basic research on the contribution of macroalgae in the future for offshore ecological environments and will provide theoretical guidance for healthy cultivation of macroalgae.

\section{MATERIALS AND METHODS}

\section{Cultures and Growth Conditions}

The conchocelis phases of a green strain (Z-26) and a redbrown strain (Z-61) of $P$. haitanensis were obtained from the Laboratory of Germplasm Improvements and Applications of Pyropia in Fujian Province. Conchocelis filaments were ripened by culturing in place at $29^{\circ} \mathrm{C}$ under photon irradiances of $10-20 \mu \mathrm{mol} /\left(\mathrm{m}^{2} \mathrm{~s}\right)$ and photoperiods of $8 \mathrm{~L}: 16 \mathrm{D}$. Then, ripe conchocelis were cultured at $21^{\circ} \mathrm{C}$ and aerated to promote the release of conchospores that would develop into thalli in 3040 days. Healthy and straight thalli with a length of $\sim 1 \mathrm{~cm}$ were selected. Then, three thalli were randomly chosen and placed in a $1 \mathrm{~L}$ flask, and four replicates were prepared for each treatment.

Throughout the culture experiment, conchocelis and thalli were semi-continuously cultured in nutrient-enriched seawater medium as in Provasoli's enrichment solution (PES) (Starr and Zeikus, 1993) except for the $\mathrm{N}$ and $\mathrm{P}$ concentrations. The $\mathrm{NO}_{3}{ }^{-}-\mathrm{N}$ and $\mathrm{PO}_{4}{ }^{3-}-\mathrm{P}$ concentrations of natural seawater were 0.61 and $0.09 \mathrm{mg} / \mathrm{L}$, respectively. The medium without $\mathrm{N}$ and $\mathrm{P}$ enrichment was labeled as NOP0. The $\mathrm{NO}_{3}{ }^{-}-\mathrm{N}$ and $\mathrm{PO}_{4}{ }^{3-}$ - $\mathrm{P}$ concentrations of the other three kinds of media were adjusted by addition of $\mathrm{NaNO}_{3}$ and $\mathrm{NaH}_{2} \mathrm{PO}_{4}$. The measured $\mathrm{N}$ concentrations of media N1P1, N2P2, and N3P3 were 1.81, 5.29 , and $13.16 \mathrm{mg} / \mathrm{L}$, respectively, and $\mathrm{P}$ concentrations were $0.19,0.65$, and $1.34 \mathrm{mg} / \mathrm{L}$, respectively. The media were boiled for one minute to avoid formation of nutrient precipitation and then cooled to room temperature $\left(21^{\circ} \mathrm{C}\right)$ before use. The cultures were aerated with filter-sterilized air, and the culture medium was 
fully replaced every three days. The thalli were placed in a $21^{\circ} \mathrm{C}$ chamber with light intensity set at $50-60 \mu \mathrm{mol} /\left(\mathrm{m}^{2} \mathrm{~s}\right)$ with a light cycle of $12 \mathrm{~L}: 12 \mathrm{D}$ and incubated for 15 days for further analysis.

\section{Experimental Design and Sample Collection}

Before each update of the medium, $100 \mathrm{~mL}$ of medium was collected from each flask and filtered with pre-combusted Whatman GF/F filters (diameter: $25 \mathrm{~mm}$, pore size: $0.7 \mu \mathrm{m}$ ) under a low vacuum. The filters were dried for POC analysis and stored at $-20^{\circ} \mathrm{C}$ to prevent POC from being decomposed by microorganisms. The filtrate $(50 \mathrm{~mL})$ was collected into a pretreated brown glass bottle and immediately stored at $-20^{\circ} \mathrm{C}$ for DOC determination. In order to minimize the potential effects of storage and degradation, the filtered samples were preserved by adding saturated $\mathrm{HgCl}_{2}$ solution to a final concentration of $50 \mathrm{mg} / \mathrm{L}$. All glassware used in the preparation of the DOC and POC samples was previously washed in $10 \% \mathrm{HCl}$ and rinsed with ultrapure water.

After 15 days of incubation, the thalli were taken from the culture flasks, and the surface water was removed using eight layers of absorbent gauze. An analytical balance was used to measure the fresh weight (FW) of blades. The fresh thalli were dried in an oven at $60^{\circ} \mathrm{C}$ until they reached a constant weight, which was recorded as dry weight (DW). The dried thalli were stored at $-20^{\circ} \mathrm{C}$ for further determination of elemental contents in tissue.

\section{Measurements}

\section{Measurement of Growth}

The DWs of thalli were measured to estimate the growth rates. The specific growth rate (SGR) was calculated according to the following formula: SGR $\left(\mathrm{d}^{-1}\right)=\ln \left(W_{f} / W_{0}\right) / 15$, where $W_{0}$ and $W_{f}$ refer to the initial and final DW of the 15 days of incubation, respectively.

\section{Tissue $\mathrm{C}, \mathrm{N}$, and $\mathrm{P}$ Contents}

The $\mathrm{C}, \mathrm{N}$, and $\mathrm{P}$ contents of tissues were measured to assess how tissue nutrient levels would be affected by the different experimental treatments. About $10 \mathrm{mg}$ dried thalli of the four different treatments were ground with a mortar and pestle. The $\mathrm{C}$ and $\mathrm{N}$ contents of algal tissue were obtained by combustion and measured with a Costech ECS CHNSO elemental analyzer (Costech Analytical Technologies, Valencia, California, United States). The tissue P content was measured by acid-persulfate digestion and subsequent soluble reactive phosphate analysis using an Automatic Discrete Analyzer (CleverChem380, DeChem-Tech. GmbH, Hamburg, Germany).

\section{Release of DOC and POC}

Particulate organic carbon (POC) samples were dried at $60^{\circ} \mathrm{C}$ before analysis and were measured using a Costech ECS CHNSO elemental analyzer. Concentrations of DOC were derived by catalytic oxidation at high temperature $\left(720^{\circ} \mathrm{C}\right)$ and chemiluminescence using a Shimadzu TOC-VCPH analyzer (TOC5000A; Shimadzu, Kyoto, Japan). The net release rates (mg $\mathrm{g}^{-1} \mathrm{DW} \mathrm{d}^{-1}$ ) of OC (as DOC and POC) by P. haitanensis were calculated as

$$
\mathrm{R}=\Delta \mathrm{OC} \times \mathrm{V} \div \mathrm{DW} \div 15
$$

where $\triangle \mathrm{OC}$ is the increase of $\mathrm{OC}$ concentration $(\mathrm{mg} / \mathrm{L})$ during 15 days of incubation; V and DW are seawater volume (L) and initial dry weight $(\mathrm{g})$ of tissue, respectively.

\section{Statistical Analysis}

All values presented represent the mean of four replicates for each treatment. Error bars in the figures depict the standard deviations. Significant differences $(P<0.05)$ between values were determined using Student's $t$-test. All statistical analyses were carried out using SPSS 19.0 version.

\section{RESULTS}

\section{Growth}

Increase of $\mathrm{N}$ and $\mathrm{P}$ concentrations had a significant effect on the growth rate of Z-61 $(P<0.05)$ while having no significant influence on Z-26 (Figure 1). For Z-61, the growth rate tended to increase from N0P0 to N2P2 treatments $(P<0.05)$, but further increase in $\mathrm{N}$ and $\mathrm{P}$ decreased the growth rate $(P<0.05)$, and no significant difference was found between N0P0 and N3P3 treatments $(P>0.05)$. In addition, the SGR of Z-61 was significantly higher than that of Z-26 under all four treatments $(P<0.05)$.

\section{Tissue C, N, and P Contents and Element Accumulation Rates}

To investigate the absorption and utilization of $\mathrm{N}$ and $\mathrm{P}$, we measured tissue nutrient content of $P$. haitanensis under varying $\mathrm{N}$ and $\mathrm{P}$ supply. $\mathrm{C}, \mathrm{N}$, and $\mathrm{P}$ contents within the algal tissue differed significantly between treatments (Figure 2). Focusing

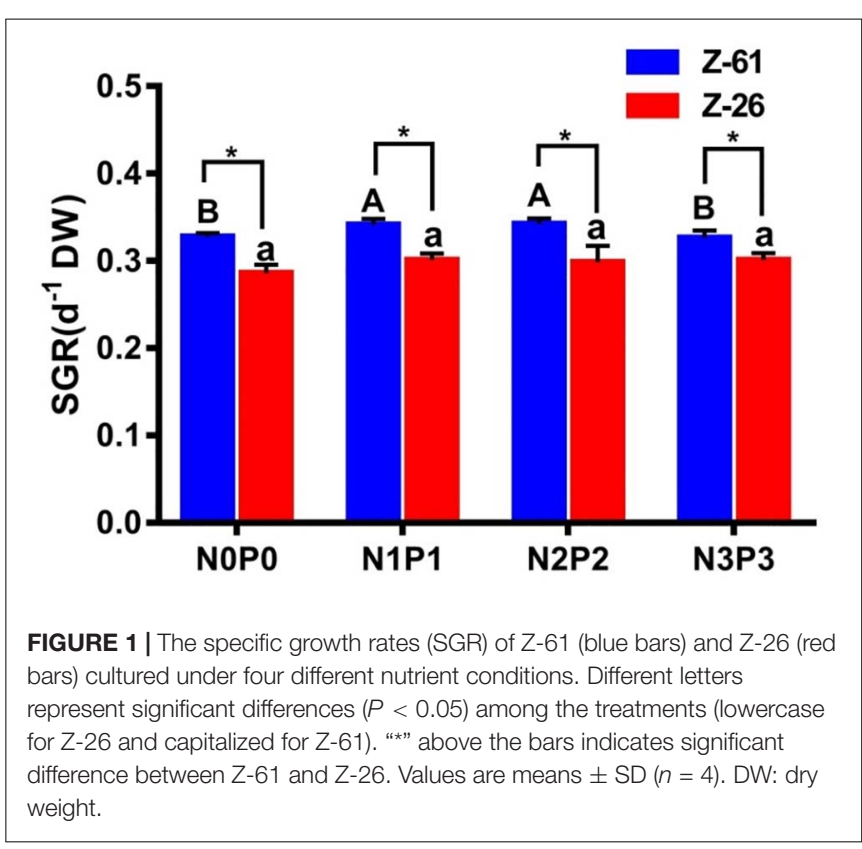


A

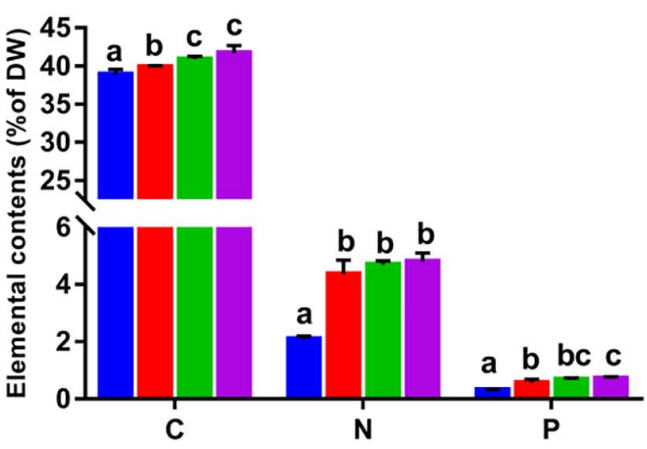

B

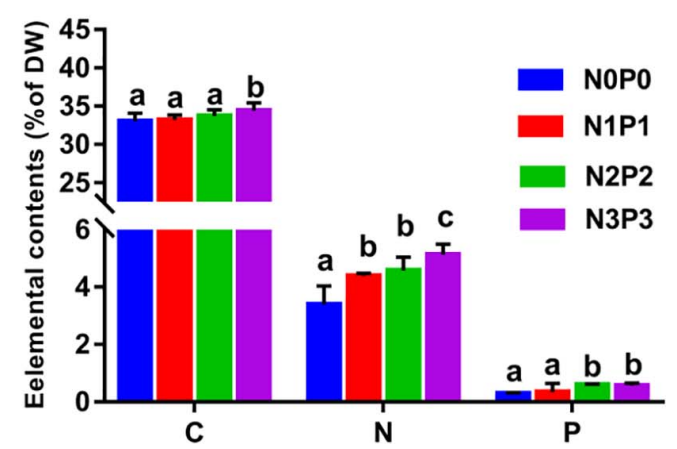

FIGURE 2 | Tissue nutrient contents of the Z-61 (A) and Z-26 (B) exposed to the different nutrient treatments. C (carbon), N (nitrogen), and P (phosphorus) contents expressed as percent of sample dry weight (DW). All data are expressed as mean \pm SD $(n=4)$, and different letters represent significant differences $(P<0.05)$ among the treatments.
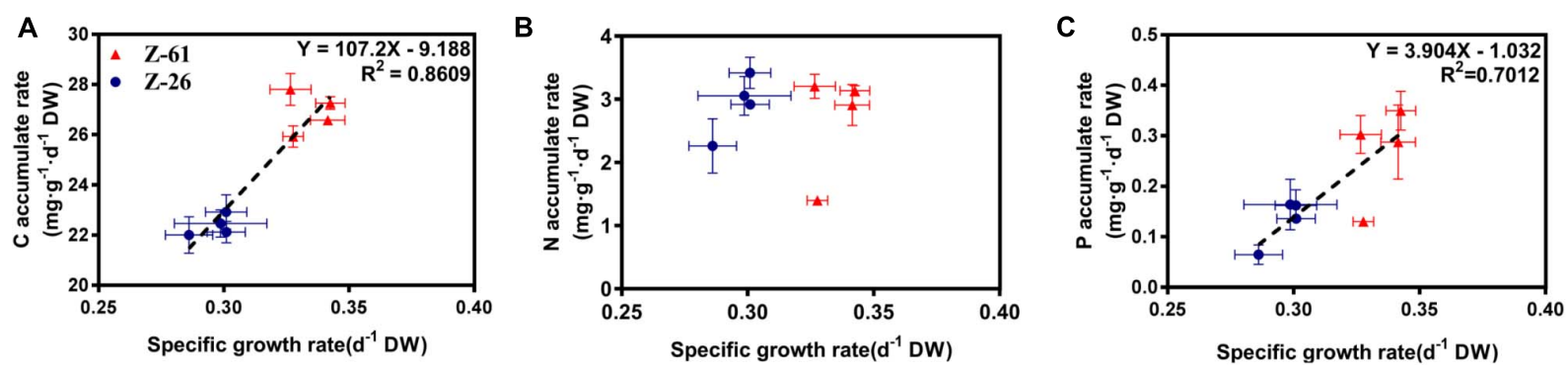

FIGURE 3 | The relationships between the specific growth rate and the accumulate rates of tissue elements of two strains of $P$. haitanensis: tissue carbon (A), nitrogen (B), and phosphorus (C).

on each strain separately, the tissue $\mathrm{C}$ content was significantly elevated under $\mathrm{N}$ and $\mathrm{P}$ enrichment $(P<0.05)$. From N0P0 to $\mathrm{N} 3 \mathrm{P} 3$, the C contents in Z-61 and Z-26 ranged from 38.9 to $41.7 \%$ and 33.0 to $34.4 \%$, respectively. In addition, the $C$ content of Z-61 was higher than that of Z-26 under the same conditions $(P<0.05)$. Both strains had higher $\mathrm{N}$ and $\mathrm{P}$ content in the elevated $\mathrm{N}$ and $\mathrm{P}$ treatment $(P<0.05)$. The $\mathrm{N}$ contents of $\mathrm{Z}-61$ and Z-26 ranged from 2.1 to $4.8 \%$ and 3.4 to $5.1 \%$, respectively. The $\mathrm{P}$ contents of Z- 61 and Z-26 ranged from 0.3 to $0.7 \%$ and 0.2 to $0.6 \%$, respectively.

We also found that the tissue $\mathrm{C}$ and $\mathrm{P}$ accumulation rates, rather than $\mathrm{N}$ accumulation rates, increased significantly with the growth rate $\left(R^{2}>0.70\right.$, Figure 3$)$. Overall, tissue $\mathrm{C}, \mathrm{N}$, and $\mathrm{P}$ contents were elevated when $P$. haitanensis was grown in $\mathrm{N}$ and $\mathrm{P}$ enriched environments, resulting in greater storage in the N3P3 treatment compared to the N0P0 treatment $(P<0.05)$.

\section{Elemental Stoichiometry}

We next investigated the elemental stoichiometry under different nutrient conditions. The elemental stoichiometry of $P$. haitanensis showed significant differences as a result of the different nutrient-loading scenarios they were exposed to Figure 4, $P<0.05$. Tissue carbon:nitrogen (C:N) showed significant changes from N0P0 to N3P3 treatment in both strains, depending on the $\mathrm{N}$-loading scenario (Figures 4A,B, $P<0.05$ ).
With increased $\mathrm{N}$ and $\mathrm{P}$ concentration, although there was no significant difference in the N1P1-N3P3 treatments, the N:P ratios remained well above the Redfield ratio. This indicated that the $\mathrm{N}$ contents of Z-61 and Z-26 thalli were limited by low $\mathrm{N}$ conditions. Carbon:phosphorus (C:P) ratios of the two strains decreased steadily, showing similar trends with the C:N ratio (Figures 4C,D). The different P-loading scenarios were reflected in the significant differences in C:P, with the lowest C:P ratios in the high-P treatment and the highest C:P ratios in the N0P0 treatment. A slightly different pattern was observed in the tissue nitrogen:phosphorus ratios $(\mathrm{N}: \mathrm{P})$, while $\mathrm{N}: \mathrm{P}$ ratios remained largely decreased in Z-26 from N0P0 to N3P3 (Figure 4F, $P<0.05)$, but there was no significant response to nutrient levels in Z-61 (Figure 4E, $P>0.05$ ). Overall, the C:N and C:P ratios were significantly decreased and approached the Redfield ratio due to the $\mathrm{N}$ and $\mathrm{P}$ enrichment. Besides, the $\mathrm{C}: \mathrm{N}$ and $\mathrm{N}: \mathrm{P}$ ratios of Z-61 are higher and lower than the $\mathrm{C}: \mathrm{N}$ and $\mathrm{N}: \mathrm{P}$ ratios of $\mathrm{Z}-26$, respectively $(P<0.05)$, which resulted in no significant effect on the C:P ratio between the two strains $(P>0.05)$.

The carbon:nutrient ratios of aquatic plants can be scaled according to their nutrient content to explore further quantitative relationships. The $\mathrm{C}, \mathrm{N}$, and $\mathrm{P}$ contents of both strains could be used to explain the variation in carbon:nutrient ratios (Figure 5). Our results indicated that increases in $\mathrm{P} \%$ and $\mathrm{N} \%$ were 


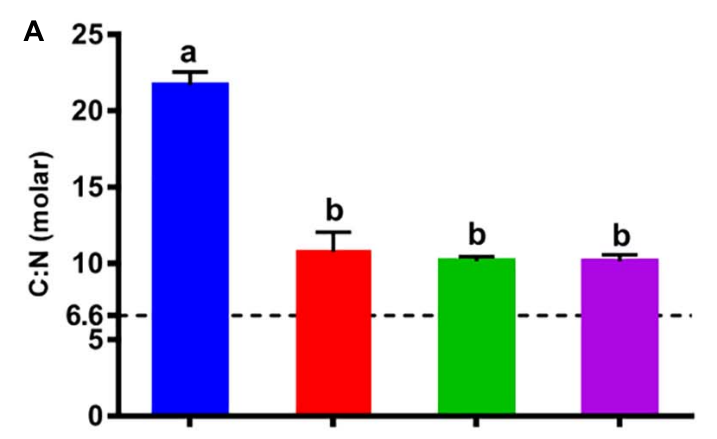

C

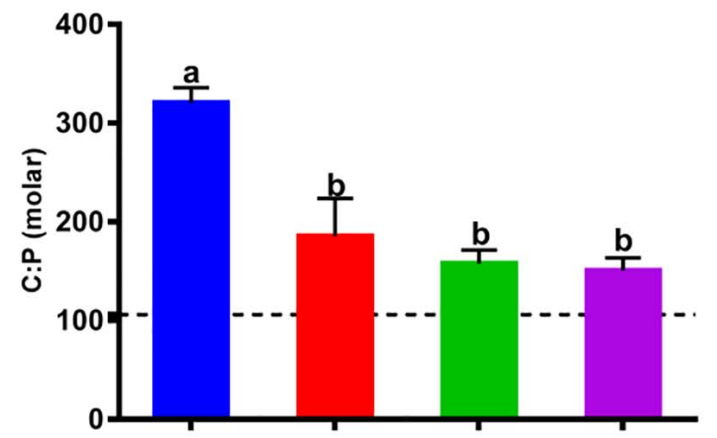

E

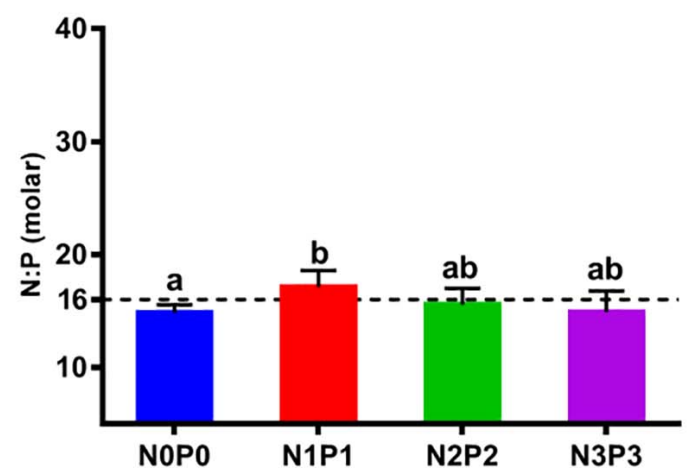

B

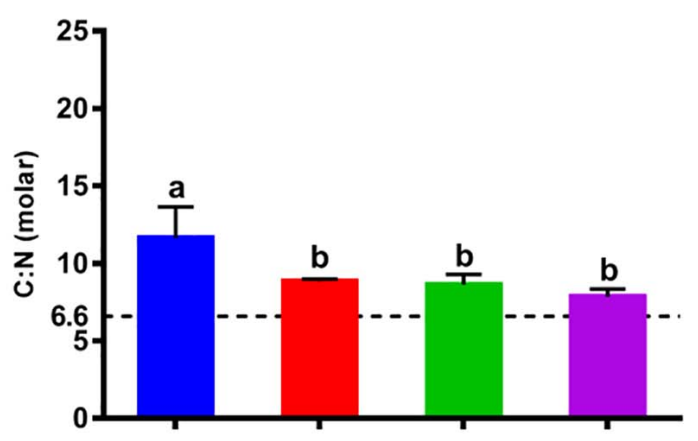

D

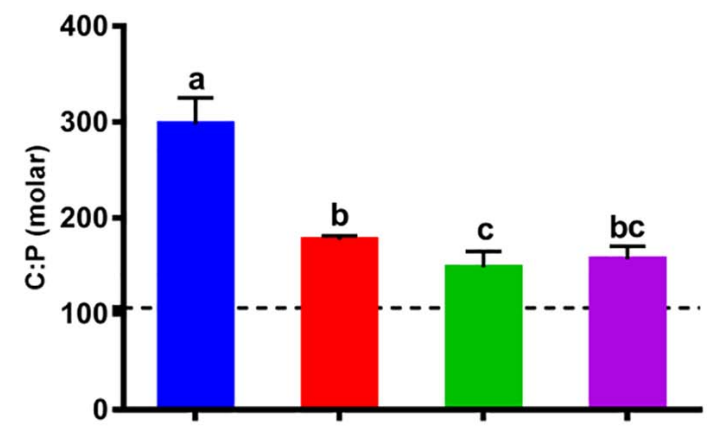

$\mathbf{F}$

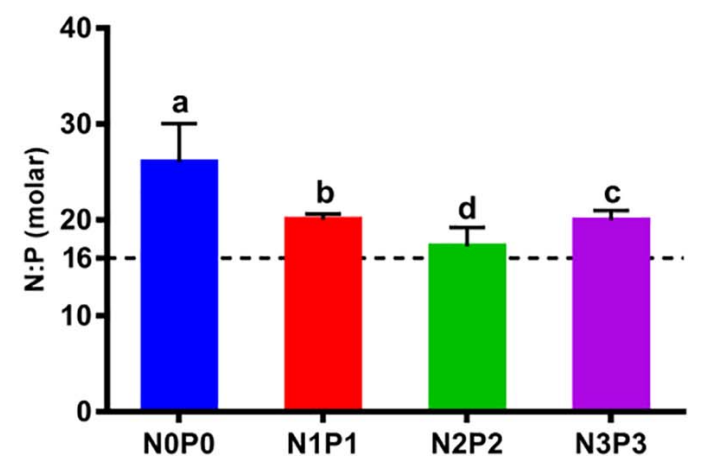

FIGURE 4 | Elemental ratios of Z-61 (A,C,E) and Z-26 (B,D,F) in the four nutrient treatments. Error bars denote standard deviations of averaged results from four replicate bottles. The straight horizontal dotted line indicates the Redfield ratio (C:N:P = 106:16:1).

associated with exponential decreases in the C:P and C:N ratios, respectively (Figure 5).

\section{Dissolved and Particulate Organic Carbon}

To investigate the role of organic carbon in the marine biogeochemical cycle, the POC and DOC release rates of the two strains during the 15-day incubation were measured. The release rates of DOC and POC differed markedly among $\mathrm{N}$ and $\mathrm{P}$ conditions (Figure 6, $P<0.05$ ). The mean release rate of POC was $0.60-1.29 \mathrm{mg} \mathrm{g}^{-1} \mathrm{~d}^{-1}$ for strain Z-61 and was $0.95-1.71 \mathrm{mg}$ $\mathrm{g}^{-1} \mathrm{~d}^{-1}$ for strain Z-26 (Figures 6A,B). The mean release rate of DOC was 2.42-5.08 $\mathrm{mg} \mathrm{g}^{-1} \mathrm{~d}^{-1}$ for strain Z-61 and was 3.61$8.22 \mathrm{mg} \mathrm{g}^{-1} \mathrm{~d}^{-1}$ for strain Z-26 (Figures 6C,D). In general, the mean DOC release rates were much higher than those of POC in both strains. It is worth noting that under the condition of N0P0 with the lowest $\mathrm{N}$ and $\mathrm{P}$ concentrations, DOC release rates were the highest for both strains (Figure 6). Additionally, the release rate of DOC had no significant difference among N1P1, N2P2, or N3P3 treatments. Similarly, under the condition of N0P0, the release rate of POC was higher than or close to those of other treatments (Figure 6). 

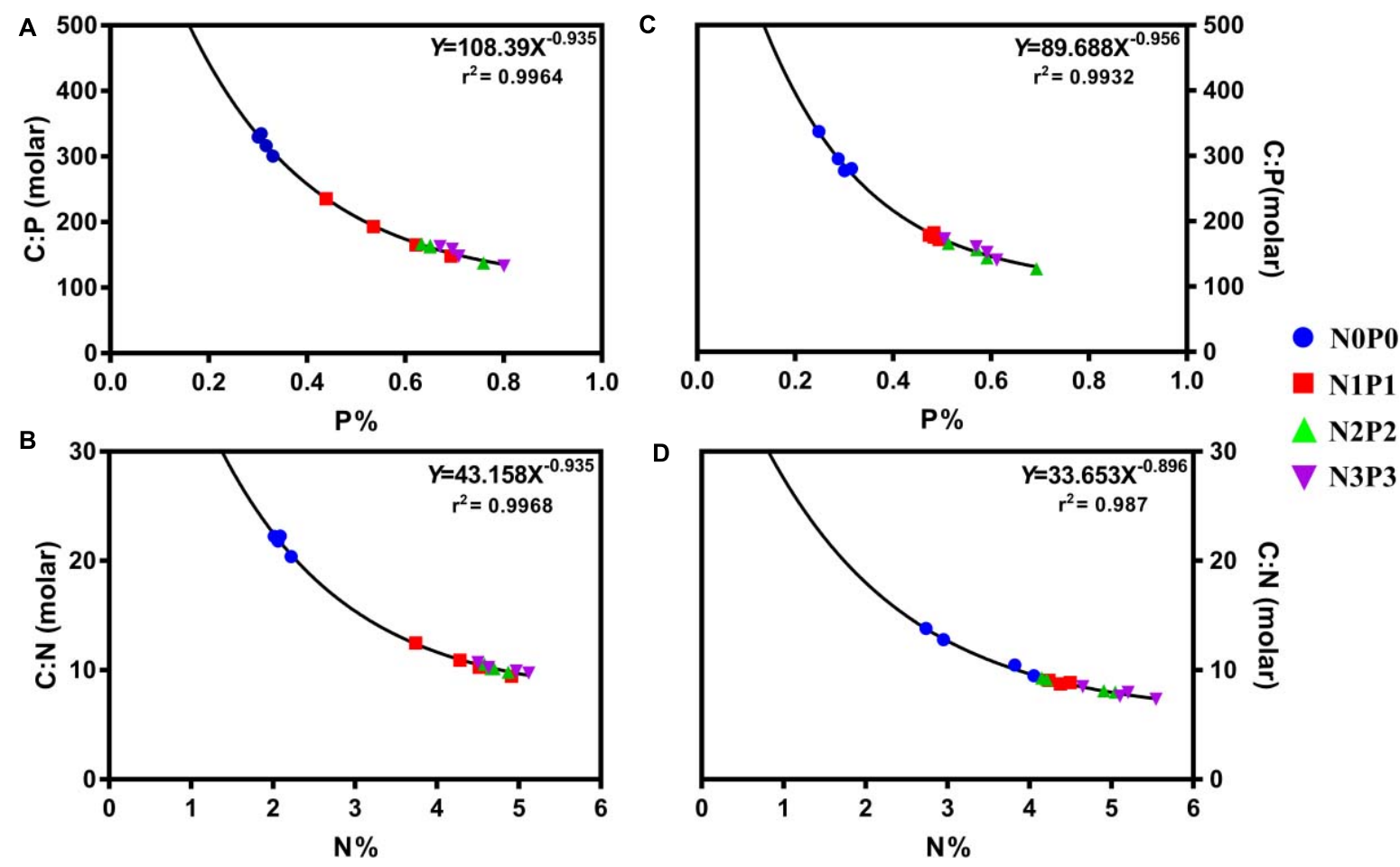

FIGURE 5 | Arithmetic relationships between nutrient contents (percentage dry weight) and nutrient molar ratios, (A) P\% and C:P ( $\left.r^{2}=0.9964\right)$ and (B) N\% and C:N $\left(r^{2}=0.9968\right)$ for Z-61; (C) P\% and C:P $\left(r^{2}=0.9932\right)$ and (D) N\% and C:N $\left(r^{2}=0.987\right)$ for Z-26.

\section{Accumulated and Released Organic Carbon}

In this study, the total carbon $\left(\mathrm{C}_{\mathrm{T}}\right)$ refers to the sum of the increased carbon contents in algal tissue and the carbon content in DOC and POC. Our results showed that both strains of $P$. haitanensis released large amounts of POC and DOC during the incubation period. The proportions of algal tissue C, DOC, and POC were different from N0P0 to N3P3 treatment in both strains (Figure 7). The mean ratios of tissue $\mathrm{C} / \mathrm{C}_{\mathrm{T}}, \mathrm{DOC} / \mathrm{C}_{\mathrm{T}}$, and POC/ $\mathrm{C}_{\mathrm{T}}$ ranged from 82.1 to $91.6 \%, 6.3$ to $14.4 \%$, and 2.1 to $4.1 \%$, respectively, for strain Z-61; and from 68.9 to $83.0 \%, 13.4$ to $25.7 \%$, and 3.6 to $5.4 \%$, respectively, for strain Z-26. Under the N0P0 treatment, the proportion of tissue $\mathrm{C}$ was the lowest, but the proportion of DOC was the highest. From N1P1 to N3P3 treatments, the proportion of tissue $\mathrm{C}$ was higher than that of NOP0, but the proportion tended to decrease with the increase of $\mathrm{N}$ and $\mathrm{P}$ concentrations. In addition, the proportions of DOC and POC were contrary to the trend of tissue $\mathrm{C}$, i.e., with the increase of $\mathrm{N}$ and $\mathrm{P}$ concentration, the proportions of POC and DOC increased gradually (Figure 7).

\section{DISCUSSION}

\section{C, N, P Contents and Ratios}

Numerous studies have shown that nutrient availability has a pronounced effect on the nutrient composition of macroalgae.
As found in the marine macroalga Chnoospora implexa, tissue $\mathrm{C}, \mathrm{N}$, and $\mathrm{P}$ contents were significantly elevated under $\mathrm{N}$ and $\mathrm{P}$ enrichment (Bender-Champ et al., 2017). Several field studies found that the marine macroalgae Pilayella littoralis, Enteromorpha intestinalis, Ulva fenestrata, Gracilaria pacifica, and Laminaria japonica could effectively take up $\mathrm{N}$ in the environment with higher $\mathrm{N}$ availability, resulting in high $\mathrm{N}$ contents in algal tissue (Lotze and Schramm, 2000; Naldi and Wheeler, 2002; Dong et al., 2011). These studies are consistent with our results suggesting that tissue $\mathrm{C}, \mathrm{N}$, and $\mathrm{P}$ contents in both strains of $P$. haitanensis were significantly increased by the $\mathrm{N}$ and $\mathrm{P}$ enrichment. Thus, $\mathrm{P}$. haitanensis was able to rapidly respond to increased $\mathrm{N}$ and $\mathrm{P}$ by taking up and storing more $\mathrm{C}$, $\mathrm{N}$, and $\mathrm{P}$ in algal tissue.

A recent study found that, under nutrient-replete conditions, the tissue $\mathrm{C}, \mathrm{N}$, and $\mathrm{P}$ accumulation rates of 11 macroalgae species linearly increased with the growth rate (Chen et al., 2020). However, the present study only found positive linear relationships between SGR and $\mathrm{C}$ accumulation rates, and between SGR and $\mathrm{P}$ accumulation rates (Figure 3). This indicates that the accumulation rates of elements can be shifted by changing nutrient conditions, which may reflect the dynamics of functional macromolecular pools or nutrient reserves. This hypothesis was supported by the findings that more pigments, proteins, or amino acids were synthesized under $\mathrm{N}$ and $\mathrm{P}$ enrichment in Ulva rigida and P. yezoensis (Gao et al., 2018, 2019). Besides, our previous study found that the total protein content of $P$. haitanensis strain Z-26 was almost double that of 


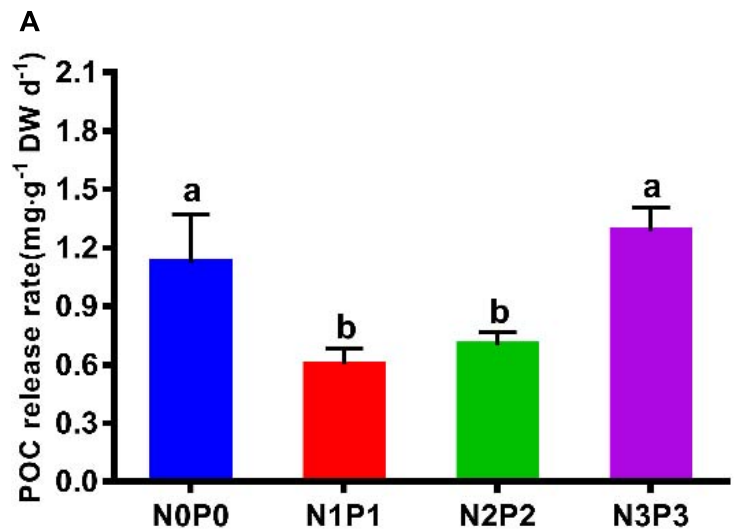

B

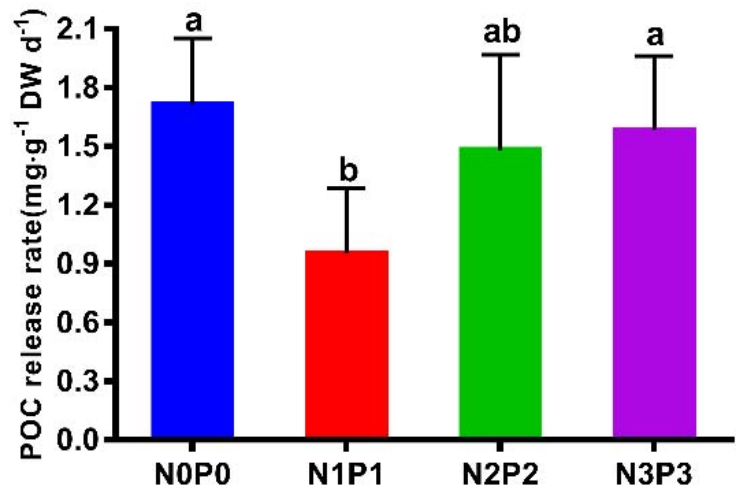

C

D
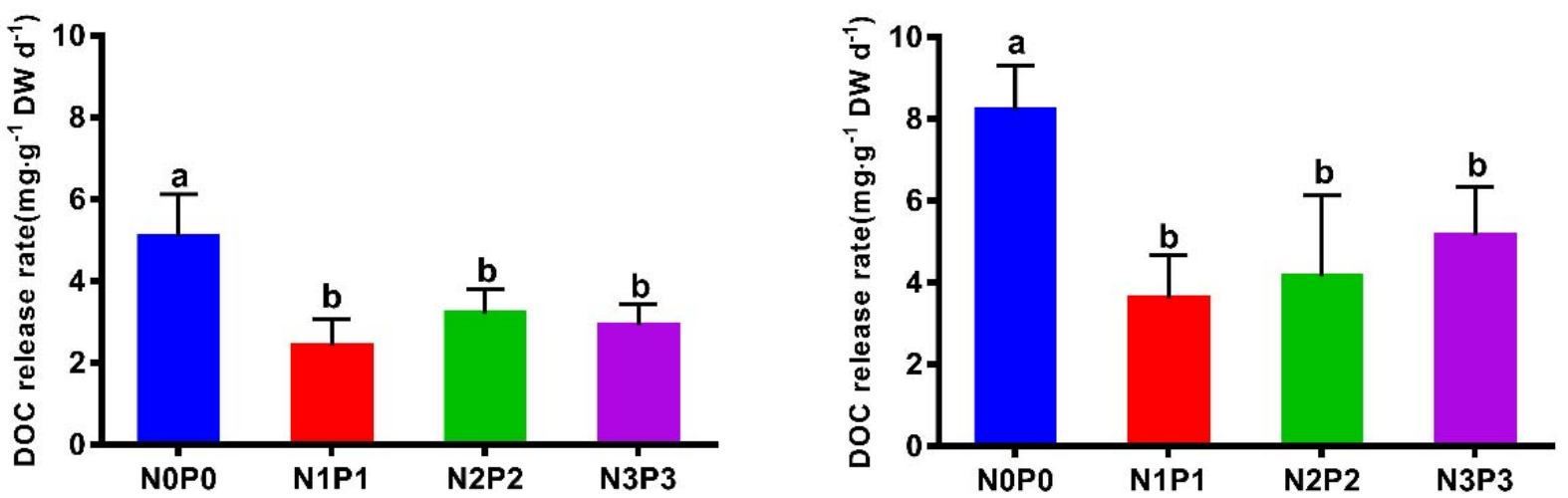

FIGURE 6 | The release rates ( $\mathrm{mg} \mathrm{g}^{-1} \mathrm{~d}^{-1} \mathrm{DW}$ ) of particulate organic carbon (POC) from Z-61 (A) and Z-26 (B) during 15-day incubation. The release rates of dissolved organic carbon (DOC) from Z-61 (C) and Z-26 (D) during 15-day incubation. All data are expressed as mean \pm SD $(n=4)$. Different letters represent significant differences $(P<0.05)$ among the treatments.

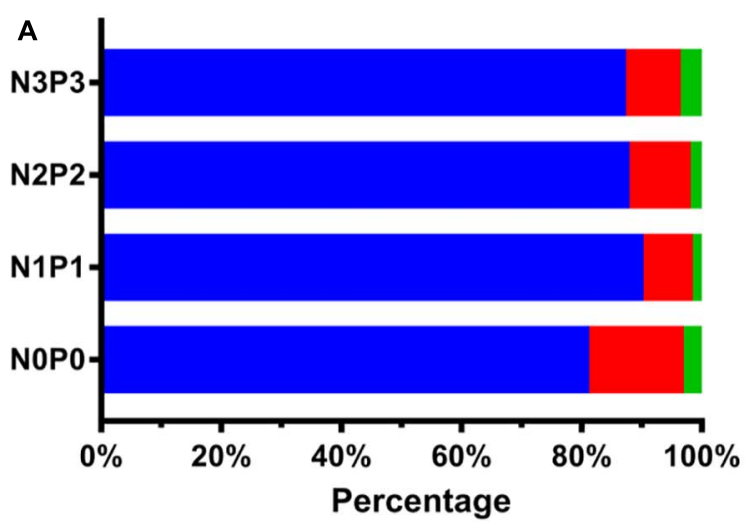

tissue C

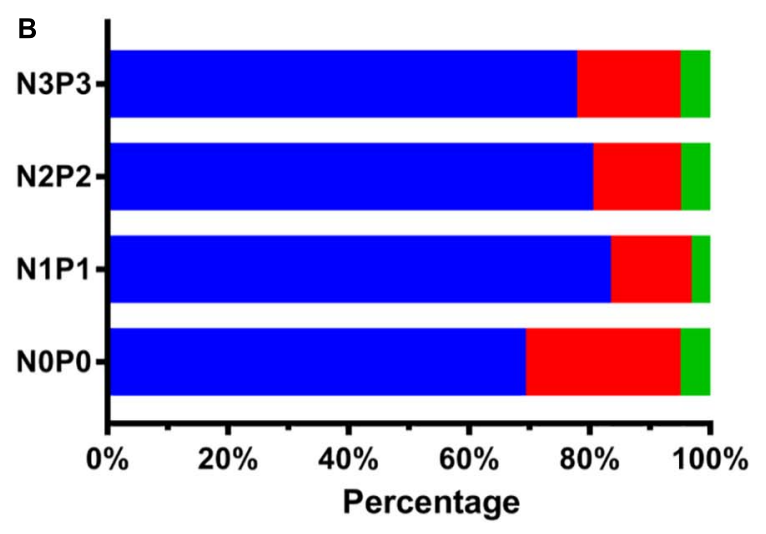

DOC POC

FIGURE 7| The percentage of organic carbons of Z-61 (A) and Z-26 (B). Bars in blue, red, and green color represent tissue carbon, dissolved organic carbon (DOC), and particulate organic carbon (POC), respectively.

strain Z-61 under the lowest nutrient condition N0P0 (Xu et al., 2020). This is consistent with the present study, which found that, under N0P0, the N content of Z-26 was $62 \%$ higher than that of Z-61, and the C:N ratio of Z-61 was about twice that of Z-26 (Figure 4). This kind of strain-specific difference on the contents of protein, the $\mathrm{N}$-enriched macromolecular, may 
result in that the $\mathrm{N}$ accumulation rates of the two strains did not linearly increase with the growth rate under four different nutrient conditions (Figure 3B).

As an economically important macroalgal species, it is necessary to analyze the responses of the C:N:P ratio of $P$. haitanensis to varying $\mathrm{N}$ and $\mathrm{P}$ concentrations to establish an index of nutrient status (Harrison and Hurd, 2001). With the data of $\mathrm{N}$ and $\mathrm{P}$ budget in a certain culture zone, and the data of $\mathrm{C}, \mathrm{N}$, and $\mathrm{P}$ contents in oceanic cultured $P$. haitanensis, the suitable cultivation scale can be roughly estimated. Researchers usually used the Redfield ratio, C:N:P = 106:16:1, as a reference to qualitatively analyze nutrient status. It is worth noting that, based on previous studies, there are significant differences on the C:N:P ratio among different species, and the ratio changes with nutritional status, whether caused by seasonal or spatial variations (Duarte, 1992; Quigg et al., 2003; Falkowski and Raven, 2013; Moore et al., 2013). This study reported that the C:N:P ratio could vary between different strains (Figure 4), and this could be due to the significant difference in elemental and protein contents. A recent study found the tissue $\mathrm{C}: \mathrm{N}: \mathrm{P}$ ratios of 11 wild macroalgae species were well above the Redfield ratio, and the ratios of 10 species decreased after five days of cultivation in nutrient-replete conditions (Chen et al., 2020). This is consistent with our results for both strains (Figure 4), and then the C:N and C:P ratios of $P$. haitanensis showed an inverse relationship to the respective concentrations of $\mathrm{N}$ and $\mathrm{P}$ (Figure 5). In general, the stoichiometric plasticity of a certain element reflects its importance for life activity-for example, $\mathrm{C}$ is more constrained than $\mathrm{N}$, and its plasticity is quite low compared to many trace metals (Moore et al., 2013). Thus, the $\mathrm{C}: \mathrm{N}$ and $\mathrm{C}: \mathrm{P}$ ratios were much higher than the Redfield ratio under $\mathrm{N}-$ and P-limited conditions, and the ratios decreased quickly by absorbing $\mathrm{N}$ and $\mathrm{P}$ once the supply was sufficient (Figure 4). This was the basic strategy to deal with the frequently changing nutritional environment.

\section{Release of Organic Carbon and Implications}

Although the culture area of macroalgal aquaculture in the world is only $0.04 \%$ of the area occupied by wild macroalgae, the potential $\mathrm{CO}_{2}$ sequestration intensity of macroalgal aquaculture is 10 times as high as wild macroalgae (Duarte et al., 2017). Besides, compared with wild macroalgae, the regular harvesting of cultured macroalgae prevents large amounts of biomass from being decomposed and re-mineralized into the ocean (Chen and $\mathrm{Xu}, 2020)$. These characteristics show that macroalgae have great potential for carbon sequestration. However, the optimal environmental conditions for developing the carbon sequestration potential of a certain macroalga species are still unknown. Our study evaluated the effects of nutrient availability on $P$. haitanensis exudate release across a wide range of nutrient conditions. The results showed that the release rate of DOC was closely related to the $\mathrm{N}$ and $\mathrm{P}$ conditions (Figure 6). The stoichiometric overflow hypothesis posits that DOC release results from an excess of fixed carbon relative to the availability of other essential nutrients such as N (Fogg, 1983). Stresses such as low nutrients, acidification, elevated temperature, and high light intensity could result in phytoplankton releasing more DOC into the surrounding environment through a combination of processes associated with leakage and exudation (Myklestad, 1995; Mueller et al., 2014; Thornton, 2014; Egea et al., 2018). The present study also found that DOC release increased with decreasing $\mathrm{N}$ and $\mathrm{P}$ concentrations (Figure 6). This is consistent with previous studies reporting that the DOC release rates of the green macroalga Cladophora glomerata and the bull kelp Nereocystis luetkeana were enhanced by $\mathrm{N}$ and $\mathrm{P}$ limitation (Wyatt et al., 2014; Weigel and Pfister, 2020). It has been reported that $\mathrm{N}$ and $\mathrm{P}$ deficiency can result in damage and aberration of algal cell membranes, even leading to autocatalytic cell death by cell lysis (Berman-Frank et al., 2010; Franklin et al., 2012). This may result in a higher DOC release rate under low $\mathrm{N}$ and $\mathrm{P}$ conditions. Considering the significant differences between laboratory and field conditions, this study suggests that further research is needed to comprehensively quantify the effects of eutrophication on the organic carbon release from macroalgae aquaculture and the mechanisms behind it.

Based on previous studies and the present study, the released DOC and POC represent a substantial percentage of gross primary production (Myklestad, 1995; Wyatt et al., 2014; Chen et al., 2020). The partitioning of organic matter between dissolved and particulate phases has bottom-up effects on the structure and function of ecosystems (Verdugo et al., 2004; Thornton, 2014). For example, more than $56 \%$ of macroalgal DOC was refractory DOC (RDOC) that cannot be efficiently utilized by consumers and decomposers (Watanabe et al., 2020), while POC can sink to the sea floor and contribute to the deposited carbon stocks in shallow oceans. This study found that the DOC release rate decreased with increasing $\mathrm{N}$ and $\mathrm{P}$ (Figure 6), suggesting that eutrophication may decrease the potential of seaweed aquaculture on the carbon sequence. In this study, the released POC was much less than DOC under various $\mathrm{N}$ and $\mathrm{P}$ conditions. In addition, the release pattern of organic matter may be influenced by environmental changes, the regular harvest of macroalgae, and the complex life cycle. A recent study reported that the average POC released by Ulva lactuca was not significantly different compared with the average DOC during the reproductive growth phase (Chen et al., 2020). Further research is needed to determine the composition of the DOC and POC released by $P$. haitanensis and to link composition to physiological status and environmental conditions.

\section{CONCLUSION}

In the present study, we found that increased $\mathrm{N}$ and $\mathrm{P}$ concentrations in seawater could promote the accumulation of $\mathrm{C}, \mathrm{N}$, and $\mathrm{P}$ in macroalgal tissue, and there was an inverse relationship between elemental ratios and contents in algal tissue. The specific growth rate of $P$. haitanensis had a positive linear correlation with the accumulation rates of algal tissue $\mathrm{C}$ and $\mathrm{P}$. This research also found that $P$. haitanensis released both DOC and POC, and more DOC than POC was released under different $\mathrm{N}$ and $\mathrm{P}$ conditions. The DOC and POC release rates were the 
highest under the low $\mathrm{N}$ and $\mathrm{P}$ conditions (NOP0), while the DOC release rate tended to decrease with $\mathrm{N}$ and $\mathrm{P}$ enrichment. The present study could help to understand the effects of ocean eutrophication on the carbon cycle in the culture zone of the economic red alga $P$. haitanensis.

\section{DATA AVAILABILITY STATEMENT}

The original contributions presented in the study are included in the article/supplementary material, further inquiries can be directed to the corresponding authors.

\section{AUTHOR CONTRIBUTIONS}

NX and KX performed the experiments and analyzed the data. KX and CX conceived and designed the experiments. NX wrote the manuscript and prepared figures. KX reviewed

\section{REFERENCES}

Bender-Champ, D., Diaz-Pulido, G., and Dove, S. (2017). Effects of elevated nutrients and $\mathrm{CO} 2$ emission scenarios on three coral reef macroalgae. Harmful Algae 65, 40-51. doi: 10.1016/j.hal.2017.04.004

Berman-Frank, I., Rosenberg, G., Levitan, O., Haramaty, L., and Mari, X. (2010). Coupling between autocatalytic cell death and transparent exopolymeric particle production in the marine cyanobacterium Trichodesmium. Environ. Microbiol. 9, 1415-1422. doi: 10.1111/j.1462-2920.2007.01257.x

Chen, S., Xu, K., Ji, D., Wang, W., Xu, Y., Chen, C., et al. (2020). Release of dissolved and particulate organic matter by marine macroalgae and its biogeochemical implications. Algal Res. 52:102096. doi: 10.1016/j.algal.2020.102096

Chen, Y., and Xu, C. (2020). Exploring new blue carbon plants for sustainable ecosystems. Trends Plant Sci. 25, 1067-1070. doi: 10.1016/j.tplants.2020.07.016

Dong, X., Gao, Z., Zhang, X., Qi, Z., and Ye, N. (2011). Evaluation of the potential role of the macroalga Laminaria japonica for alleviating coastal eutrophication. Bioresour. Technol. 102, 9912-9918. doi: 10.1016/j.biortech.2011.08.035

Duarte, C. M. (1992). Nutrient concentration of aquatic plants: patterns across species. Limnol. Oceanogr. 37, 882-889.

Duarte, C. M., and Cebrián, J. (1996). The fate of marine autotrophic production. Limnology and Oceanography 41, 1758-1766. doi: 10.4319/lo.1996.41.8.1758

Duarte, C. M., Jiaping, W., Xi, X., Annette, B., and Dorte, K. J. (2017). Can seaweed farming play a role in climate change mitigation and adaptation? Front. Mar. Sci. 4:100. doi: 10.3389/fmars.2017.00100

Egea, L. G., Jimenez-Ramos, R., Hernandez, I., Bouma, T. J., and Brun, F. G. (2018). Effects of ocean acidification and hydrodynamic conditions on carbon metabolism and dissolved organic carbon (DOC) fluxes in seagrass populations. PLoS One 13:e0192402. doi: 10.1371/journal.pone.0192402

Falkowski, P. G., and Raven, J. A. (2013). Aquatic Photosynthesis. Princeton, NJ: Princeton University Press.

FAO, (2018). FAO Yearbook: Fishery and Aquaculture Statistics, 2018. Rome: FAO.

Fogg, G. E. (1983). The ecological significance of extracellular products of phytoplankton photosynthesis. Bot. Mar. 26, 3-14. doi: 10.1515/botm.1983. 26.1.3

Franklin, D. J., Airs, R. L., Fernandes, M., Bell, T. G., Bongaerts, R. J., Berges, J. A., et al. (2012). Identification of senescence and death in Emiliania huxleyi and Thalassiosira pseudonana: cell staining, chlorophyll alterations, and dimethylsulfoniopropionate (DMSP) metabolism. Limnol. Oceanogr. 57, 305-317. doi: 10.4319/lo.2012.57.1.0305

Gao, G., Clare, A. S., Chatzidimitriou, E., Rose, C., and Caldwell, G. (2018). Effects of ocean warming and acidification, combined with nutrient enrichment, on chemical composition and functional properties of Ulva rigida. Food Chem. 258, 71-78. doi: 10.1016/j.foodchem.2018.03.040 drafts of the manuscript. WW, YX, DJ, and CC reviewed the manuscript. All authors contributed to the article and approved the submitted version.

\section{FUNDING}

We gratefully acknowledge funding from the National Key Research and Development Program of China (2018YFD0900702 and 2018YFD0901506), the National Natural Science Foundation of China (41806183), and the China Agriculture Research System (CARS-50), and the Training Program of the National Foundation of Jimei University.

\section{ACKNOWLEDGMENTS}

We thank LetPub (www.letpub.com/) for its linguistic assistance during the preparation of this manuscript.

Gao, G., Clare, A. S., Rose, C., and Caldwell, G. S. (2017). Eutrophication and warming-driven green tides (Ulva rigida) are predicted to increase under future climate change scenarios. Mar. Pollut. Bull. 114, 439-447. doi: 10.1016/j. marpolbul.2016.10.003

Gao, G., Gao, Q., Bao, M., Xu, J., and Li, X. (2019). Nitrogen availability modulates the effects of ocean acidification on biomass yield and food quality of a marine crop Pyropia yezoensis. Food Chem. 271, 623-629. doi: 10.1016/j.foodchem. 2018.07.090

Giordano, M., Beardall, J., and Raven, J. A. (2005). CO2 concentrating mechanisms in algae: mechanisms, environmental modulation, and evolution. Annu. Rev. Plant Biol. 56, 99-131.

Gruber, N., and Deutsch, C. A. (2014). Redfield's evolving legacy. Nat. Geosci. 7, 853-855. doi: 10.1038/ngeo2308

Harrison, P. J., and Hurd, C. L. (2001). Nutrient physiology of seaweeds: application of concepts to aquaculture. Cahiers Biol. Mar. 42, 71-82.

Jiao, N., Herndl, G. J., Hansell, D. A., Benner, R., Kattner, G., Wilhelm, S. W., et al. (2010). Microbial production of recalcitrant dissolved organic matter: long-term carbon storage in the global ocean. Nat. Rev. Microbiol. 8:593. doi: 10.1038/nrmicro2386

Krause-Jensen, D., and Duarte, C. M. (2016). Substantial role of macroalgae in marine carbon sequestration. Nat. Geosci. 9, 737-742. doi: 10.1038/ngeo2790

Lobban, C. S., Harrison, P. J., and Harrison, P. J. (1994). Seaweed Ecology and Physiology. Cambridge, MA: Cambridge University Press.

Lotze, H. K., and Schramm, W. (2000). Ecophysiological traits explain species dominance patterns in macroalgal blooms. J. Phycol. 36, 287-295. doi: 10.1046/ j.1529-8817.2000.99109.x

Mann, K. (1973). Seaweeds: their productivity and strategy for growth. Science 182 975-981. doi: 10.1126/science.182.4116.975

Moore, C. M., Mills, M. M., Arrigo, K. R., Berman-Frank, I., Bopp, L., Boyd, P. W. et al. (2013). Processes and patterns of oceanic nutrient limitation. Nat. Geosci. 6, 701-710. doi: 10.1038/ngeo1765

Mueller, B., van der Zande, R. M., van Leent, P. J. M., Meesters, E. H., Vermeij, M. J. A., and van Duyl, F. C. (2014). Effect of light availability on dissolved organic carbon release by Caribbean reef algae and corals. Bull. Mar. Sci. 90, 875-893. doi: 10.5343/bms.2013.1062

Myklestad, S. M. (1995). Release of extracellular products by phytoplankton with special emphasis on polysaccharides. Sci. Total Environ. 165, 155-164. doi: 10.1016/0048-9697(95)04549-G

Naldi, M., and Wheeler, P. A. (2002). Changes in nitrogen pools in Ulva fenestrata (Chlorophyta) and Gracilaria pacifica (Rhodophyta) under nitrate and ammonium enrichment. J. Phycol. 35, 70-77. doi: 10.1046/j.1529-8817. 1999.3510070.x 
Ortega, A., Geraldi, N. R., Alam, I., Kamau, A. A., Acinas, S. G., Logares, R., et al. (2019). Important contribution of macroalgae to oceanic carbon sequestration. Nat. Geosci. 12, 748-754. doi: 10.1038/s41561-0190421-8

Quigg, A., Finkel, Z. V., Irwin, A. J., Rosenthal, Y., Ho, T. Y., Reinfelder, J. R., et al. (2003). The evolutionary inheritance of elemental stoichiometry in marine phytoplankton. Nature 425, 291-294.

Rabalais, N. N., Eugene, T. R., Díaz, R., and Dubravko, J. (2009). Global change and eutrophication of coastal waters. ICES J. Mar. Sci. 7, 1528-1537. doi: 10.1093/ icesjms/fsp047

Redfield, A., Redfield, A., Redfield, A. C., and Redfield, J. (1934). On the Proportions of Organic Derivations in Sea Water and Their Relation to the Composition of Plankton. Liverpool: University Press of Liverpool.

Starr, R. C., and Zeikus, J. A. (1993). Utex-the culture collection of algae at the University of Texas At Austin 1993 list of cultures 1. J. Phycol. 29, 1-106. doi: 10.1111/j.0022-3646.1993.00001.x

Strokal, M., Yang, H., Zhang, Y., Kroeze, C., Li, L., Luan, S., et al. (2014). Increasing eutrophication in the coastal seas of China from 1970 to 2050. Mar. Pollut. Bull. 85, 123-140. doi: 10.1016/j.marpolbul.2014.06.011

Teichberg, M., Fox, S. E., Olsen, Y. S., Valiela, I., Martinetto, P., Iribarne, O., et al. (2010). Eutrophication and macroalgal blooms in temperate and tropical coastal waters: nutrient enrichment experiments with Ulva spp. Glob. Change Biol. 16, 2624-2637. doi: 10.1111/j.1365-2486.2009. 02108.x

Thornton, D. C. O. (2014). Dissolved organic matter (DOM) release by phytoplankton in the contemporary and future ocean. Eur. J. Phycol. 49, 20-46. doi: 10.1080/09670262.2013.875596

Tong, Y., Zhao, Y., Zhen, G., Chi, J., Liu, X., Lu, Y., et al. (2015). Nutrient loads flowing into coastal waters from the main rivers of China (2006-2012). Sci. Rep. 5:16678. doi: $10.1038 /$ srep 16678

Verdugo, P., Alldredge, A. L., Azam, F., Kirchman, D. L., Passow, U., and Santschi, P. H. (2004). The oceanic gel phase: a bridge in the DOMPOM continuum. Mar. Chem. 92, 67-85. doi: 10.1016/j.marchem.2004. 06.017

Wahl, M., Molis, M., Hobday, A. J., Dudgeon, S., Neumann, R., Steinberg, P., et al. (2015). The responses of brown macroalgae to environmental change from local to global scales: direct versus ecologically mediated effects. Perspect. Phycol. 2 , 11-29. doi: 10.1127/pip/2015/0019

Watanabe, K., Yoshida, G., Hori, M., Umezawa, Y., Moki, H., and Kuwae, T. (2020). Macroalgal metabolism and lateral carbon flows can create significant carbon sinks. Biogeosciences 17, 2425-2440. doi: 10.5194/bg-17-2425-2020

Weigel, B. L., and Pfister, C. A. (2020). The dynamics and stoichiometry of dissolved organic carbon release by kelp. Ecology 5:e03221. doi: 10.1002/ecy. 3221

Wyatt, K. H., Tellez, E., Woodke, R. L., Bidner, R. J., and Davison, I. R. (2014). Effects of nutrient limitation on the release and use of dissolved organic carbon from benthic algae in Lake Michigan. Freshw. Sci. 33, 557-567. doi: 10.1086/ 675453

Xiao, X., Agusti, S., Lin, F., Li, K., Pan, Y., Yu, Y., et al. (2017). Nutrient removal from Chinese coastal waters by large-scale seaweed aquaculture. Sci. Rep. 7:46613. doi: 10.1038/srep46613

Xiao, X., Agusti, S., Yu, Y., Huang, Y., Chen, W., Hu, J., et al. (2021). Seaweed farms provide refugia from ocean acidification. Sci. Total Environ. 776:145192. doi: 10.1016/j.scitotenv.2021.145192

Xu, N., Xu, K., Wang, W., Xu, Y., Ji, D., Chen, C., et al. (2020). Nutrient enrichment improves growth and food quality of two strains of the economic seaweed Pyropia haitanensis. Front. Mar. Sci. doi: 10.3389/fmars.2020.544582

Yang, Y., Chai, Z., Wang, Q., Chen, W., He, Z., and Jiang, S. (2015). Cultivation of seaweed Gracilaria in Chinese coastal waters and its contribution to environmental improvements. Algal Res. 9, 236-244. doi: 10.1016/j.algal.2015. 03.017

Conflict of Interest: The authors declare that the research was conducted in the absence of any commercial or financial relationships that could be construed as a potential conflict of interest.

Copyright (c) $2021 \mathrm{Xu}$, Wang, Xu, Ji, Chen, Xie and Xu. This is an open-access article distributed under the terms of the Creative Commons Attribution License (CC BY). The use, distribution or reproduction in other forums is permitted, provided the original author(s) and the copyright owner(s) are credited and that the original publication in this journal is cited, in accordance with accepted academic practice. No use, distribution or reproduction is permitted which does not comply with these terms. 